\title{
TINJAUAN YURIDIS PENANGANAN TINDAK PIDANA HOAKS CORONA DI MEDIA SOSIAL OLEH KEPOLISIAN REBUBLIK INDONESIA
}

\author{
Yeni Nuraeni, S.H., M.H ${ }^{1}$ \\ Arif Rahmat Hidayat ${ }^{2}$
}

\begin{abstract}
ABSTRAK
Hoax merupakan penyebaran berita bohong yang seringkali mempergunakan akses telematika seperti media sosial. Perbuatan tersebut termasuk dalam ruang lingkup kejahatan siber. Penegakan hukum dalam bidang telematika seringkali berbenturan dengan cara pengungkapan ekspresi yang disalahgunakan oleh oknum tidak bertanggungjawab, melalui penyebaran kontenkonten bohong dan menyesatkan, salah satunya tentang corona. Untuk membatasi perilaku kejahatan-kejahatan baru di media sosial, maka diperlukan upaya penanganan hukum berdasarkan Undang-Undang Nomor 11 tahun 2008 tentang informasi dan transaksi elektronik yang telah diubah dengan Undang-Undang Nomor 19 tahun 2016.

Metode penelitian menggunakan spesifikasi deskripitf analitis dengan pendekatan yuridis normatif dalam mengkaji peraturan perundang-undangan. Pengumpulan data bersumber dari bahan hukum primer, sekunder maupun tersier dengan tahapan penelitian melalui studi kepustakaan, dan studi lapangan. Teknik pengumpulan data dilakukan dengan reduksi data, penyajian dan penarikan kesimpulan kemudian dianalisis secara evaluasi, interprestasi, dan konstruksi.

Hasil penelitian menunjukkan bahwa analisis tindak pidana hoaks virus corona di media sosial meliputi konten mengelabui/gurauan (Satire), menyesatkan (Misleading), meniru (Imposter), memalsukan (Fabricated), menyalahi (False), manipulasi (Manipulated) dan aksi vandalisme. Penanganan tindak pidana hoaks corona oleh Kepolisian, meliputi 1) Penerbitan Maklumat Kapolri; 2) Layanan Tanggap Covid-19, 3) Patroli Siber, dan 4) Sosialisasi tentang hoax di media sosial. Penelitian ini disimpulkan bahwa tindak pidana hoaks corona di media sosial termasuk kejahatan siber dengan upaya penyebaran berita bohong dan menyesatkan publik, yang dalam undang-undang informasi dan transaksi elektronik diancam dengan sanksi penjara selama 6 tahun.
\end{abstract}

Kata Kunci : Pidana, Hoax, Corona, Media, Sosial

\footnotetext{
${ }^{1}$ Dosen Fakultas Hukum Universitas Majalengka, email yeninur446@gmail.com Mahasiswa Fakultas Hukum Universitas Majalengka, email arifrahmathidayat0402@gmail.com
} 


\section{A. Latar Belakang Masalah}

Sektor informasi dan transaksi elektronik merupakan aspek penting dalam tatanan kehidupan masyarakat dalam upaya pemenuhan hidup manusia secara asasi, baik secara individu maupun sosial. Terutama di masa pandemic corona virus disease 2019 (covid-19) semenjak akhir tahun 2019 hingga berbulan-bulan di tahun 2020. Seiring dengan penetapan covid-19 sebagai bencana nasional sesuai Keputusan Presiden Republik Indonesia Nomor 12 Tahun 2020. ${ }^{3}$ Maka dilakukanlah penanganan covid-19 mulai dari social distancing, stay at home, physical distancing, Pembatasan Sosial Berskala Besar (PSBB) yang dilakukan pemerintah Sehingga akses elektronik merupakan hal penting dalam upaya informasi penanganannya.

"Kemajuan dan perkembangan teknologi, khususnya telekomunikasi, multimedia dan teknologi informasi (telematika) pada akhirnya dapat merubah tatanan organisasi dan hubungan sosial kemasyarakatan". Informasi elektronik di saat pandemic merupakan aspek vital untuk memberitakan informasi secara cepat dan tepat kepada masyarakat, terkait status bahaya dan kerentanan covid-19 yang dapat mengancam nyawa manusia.

Saat upaya percepatan dalam penanganan penularan covid-19 gencargencarnya dilakukan negara, namun mereka para oknum pengguna medsos, bukannya turut serta berperan positif sebagai relawan yang membantu penanganan. Tetapi mereka justru memanfaatkan situasi dan keadaan tersebut untuk berbagai kepentingan dengan bertindak buruk melalui konten-konten hoax di media sosial. Salah satunya dengan penyebaran berita bohong seputar corona di media sosial, dalam kategori tindak pidana telematika.

Pemanfaatan media sosial bersifat global terhubung pada berbagai belahan dunia seperti Whatsappp, facebook, Instagram, youtube dan lainya. Sehingga penyebaran berita bohong termasuk salah satu kejahatan siber (cyber crime) yang dapat mengancam suatu negara. "Cyber Crime merupakan kegiatan yang memanfaatkan komputer sebagai media yang didukung oleh sistem telekomunikasi baik itu dial up system, menggunakan jalur telepon, ataukah wireless system yang menggunakan antena khusus yang nirkabel".

Munculnya beberapa kasus kejahatan siber salah satunya berita bohong, telah menjadi ancaman stabilitas nasional. Hal ini berkenaan dengan kondisi wabah covid-19 yang sedang melanda, diperparah lagi dengan munculnya aksi-aksi berita bohong (Hoax) dan menyesatkan di media sosial terkait corona, cenderung berdampak buruk terhadap masyarakat. Adanya isu

${ }^{3}$ Keputusan Presiden Republik Indonesia Nomor 12 Tahun 2020 tentang Penetapan Bencana Nonalam Penyebaran Corona Virus Disease 2019 (Covid-19) Sebagai Bencana Nasional.

${ }^{4}$ Dikdik Mansur dan Elisatris Gultom. Cyver Law. Aspek Hukum Teknologi Informasi. Jakarta : Refika Adityama, 2009. hlm:2.

${ }_{5}$ Maskun. Kejahatan Siber. Cyber Crime. Suatu Pengantar. Jakarta : Kencana. 2013, hlm: 45. 
PRESUMPTION of LAW

Fakultas Hukum Universitas Majalengka

Volume 3 Nomor 1 April 2021

yang tidak benar mengenai corona, adanya tuduhan-tuduhan terhadap yang positif terkena corona, sehingga berdampak adanya saling curiga diantara masyarakat yang asalnya dari dunia maya menjadi nyata dalam kenyataan.

Guna menciptakan kepastian hukum, Indonesia memiliki UndangUndang Republik Indonesia Nomor 11 Tahun 2008 tentang Informasi dan Transaksi Elektronik (ITE) merupakan payung hukum di Indonesia untuk pertama kali dalam bidang Teknologi Informasi dan Transaksi Elektronik. Kemudian dilakukan beberapa perubahan dengan lahirnya Undang-Undang Republik Indonesia Nomor 19 Tahun 2016 Tentang Perubahan Atas UndangUndang Nomor 11 tahun 2008 tentang Informasi dan Transaksi Elektronik. Berota Bohong diatur dalam Pasal $28:{ }^{6}$

(1) Setiap Orang dengan sengaja dan tanpa hak menyebarkan berita bohong dan menyesatkan yang mengakibatkan kerugian konsumen dalam Transaksi Elektronik.

(2) Setiap Orang dengan sengaja dan tanpa hak menyebarkan informasi yang ditujukan untuk menimbulkan rasa kebencian atau permusuhan individu dan/atau kelompok masyarakat tertentu berdasarkan atas suku, agama, ras, dan antargolongan (SARA).

Konstruksi perluasan UU ITE menjelaskan perkembangan modus kejahatan dengan media komputer atau internet seperti halnya dalam bentuk hoax. "Hal tersebut sangat penting khususnya membantu penegak hukum dalam memproses dan mengadili kasus-kasus yang telah menggunakan media informasi elektronik untuk memuluskan kejahatan yang dilakukan". 7 Upaya penanganan hukum diantaranya dalam Pasal 45A (1) bahwa :

Setiap Orang yang dengan sengaja dan tanpa hak menyebarkan berita bohong dan menyesatkan yang mengakibatkan kerugian konsumen dalam Transaksi Elektronik sebagaimana dimaksud dalam Pasal 28 Ayat (1) dipidana dengan pidana penjara paling lama 6 (enam) tahun dan/atau denda paling banyak Rp 1.000.000.000,00 (satu miliar rupiah).

Sesuai latar belakang masalah tersebut diatas, maka penulis tertarik untuk membahas permasalahan tersebut dengan judul "Tinjauan Yuridis Penanganan Tindak Pidana Hoaks Corona Di Media Sosial Oleh Kepolisian Republik Indonesia.

\footnotetext{
${ }^{6}$ Pasal 28, Undang-Undang Nomor 19 Tahun 2016 Tentang Perubahan Atas UndangUndang Nomor 11 Tahun 2008 Tentang Informasi dan Transaksi Elektronik.

Maskun. Op.Cit, hlm: 34.
} 


\section{B. Identifikasi Masalah}

Sesuai dengan uraian latar belakang tersebut di atas, maka dapat diidentifikasi permasalahannya sebagai berikut :

1. Bagaimana analisis tindak pidana hoaks virus corona di media sosial?

2. Bagaimana penanganan tindak pidana hoaks virus corona di media sosial oleh Kepolisian secara yuridis ditinjau berdasarkan Pasal 45A UU No 19 Tahun 2016 tentang Tentang Perubahan Atas Undang-Undang Nomor 11 Tahun 2008 Tentang Informasi Dan Transaksi Elektronik. ?

\section{Tujuan Penelitian}

Dari hasil identifikasi, maka penelitian ini bertujuan untuk:

1. Mengetahui analisis tindak pidana hoaks virus corona di media sosial.

2. Mengetahui upaya penanganan tindak pidana hoaks virus corona di media sosial oleh kepolisian secara yuridis ditinjau berdasarkan Pasal 45A.

\section{Metode Penelitian}

\section{Spesifikasi Penelitian}

Spesifikasi penelitian adalah "konsekuensi pemilihan topik permasalahan yang akan dikaji dalam penelitian". ${ }^{8}$ Spesifikasi penelitian ini menggunakan pendekatan deskriptif analitis yang dimaksudkan untuk mengetahui makna yang dikandung oleh istilah-istilah hukum yang berkaitan dengan peraturan perundang-undangan secara konsepsional dan penerapannya dalam praktik hukum dengan tujuan agar menghasilkan simpulan mengenai kualifikasi dan mekanisme pelanggaran berdasarkan peraturan perundang-undangan.

\section{Metode Pendekatan}

Metode pendekatan yang dipakai dalam penelitian ini menggunakan metode kualitatif dengan pendekatan penelitian hukum Yuridis Normatif atau legal apphroach, yaitu "Penelitian yang difokuskan untuk mengkaji penerapan kaidah-kaidah atau norma-norma dalam hukum positif". 9 Dalam penelitian ini peneliti menggunakan jenis pendekatan normatif berdasarkan pendekatan undang-undang (statute approach) dilakukan dengan menelaah semua undang-undang dan regulasi yang bersangkut paut dengan isu hukum yang sedang ditangani.

Dalam penelitian ini menelaah peraturan yang berkaitan dengan tindak pidana hoax di media sosial. berdasarkan Undang-Undang Republik Indonesia Nomor 19 Tahun 2016 tentang Perubahan Atas Undang-Undang

8 Johnny Ibrahim. Teori dan Metodologi Penelitian Hukum Normatif. Malang: Banyumedia. 2013, hlm: 295. hlm:133.

\footnotetext{
Peter Mahmud Marzuki. Penelitian Hukum Normatif. Jakarta: Kencana. 2005,
} 
PRESUMPTION of LAW

Fakultas Hukum Universitas Majalengka

Volume 3 Nomor 1 April 2021

Nomor 11 Tahun 2008 Tentang Informasi Dan Transaksi Elektronik. Aturan yang diteliti merupakan sistem yang tertutup, artinya terpisah dari aspek-aspek yang lain, seperti sosial, budaya dan sebagainya. Peneliti tidak meninggalkan sifat dari pendekatan Undang-undang ini yaitu : ${ }^{10}$

a. Comprehensive artinya norma-norma hukum yang ada di dalamnya terkait antara satu dengan lain secara logis.

b. All-inclusive bahwa kumpulan norma hukum tersebut cukup mampu menampung permasalahan hukum yang ada, sehingga tidak akan ada kekurangan hukum.

c. Systematic bahwa disamping bertautan antara satu dengan yang lain, Norma-Norma hukum tersebut juga tersusun secara hierarkis.

\section{E. Kerangka Pemikiran}

Kerangka pemikiran adalah landasan penelitian sebagai pijakan penliti agar penelitian menjadi kokoh dan memiliki landasan yang kuat sehingga penelitian tersebut dapat diandalkan (reliable). Sebagai pijakan penulis dalam penelitian ini, serta untuk membantu penulis dalam penyusunan Artikel hukum ini digunakan beberapa teori hukum diantaranya teori teori penegakan hukum, teori kewenangan dan teori perilaku hukum kaitannya dengan perilaku pidana penyebaran berita bohong di media sosial sebagai berikut:

1. Teori Penegakan

Secara konsepsional, inti dan arti penegakan hukum terletak pada kegiatan menyerasikan hubungan nilai-nilai yang terjabarkan didalam kaidah-kaidah yang mantap dan mengejawantah dan sikap tindak sebagai rangkaian penjabaran nilai tahap akhir, untuk menciptakan, memelihara, dan mempertahankan kedamaian pergaulan hidup.

Penegakan hukum dalam transaksi informasi dan elektronik salah satunya merupakan kewenangan Kepolisian dalam upaya penangannya termasuk penyidikan sampai penuntutan dalam hal pemberitaan dan penyaiaran. Dalam hal ini kepolisian memiliki hak khusus dalam intersepsi. Pasal 5 Ayat (2) bahwa: ${ }^{11}$

Khusus untuk Informasi Elektronik dan/atau Dokumen Elektronik berupa hasil intersepsi atau penyadapan atau perekaman yang merupakan bagian dari penyadapan harus dilakukan dalam rangka penegakan hukum atas permintaan kepolisian, kejaksaan, dan/atau institusi lainnya yang kewenangannya ditetapkan berdasarkan undang-undang. 
Pasal 43 (2) bahwa : ${ }^{12}$

Penyidikan di bidang Teknologi Informasi dan Transaksi Elektronik dilakukan dengan memperhatikan perlindungan terhadap privasi, kerahasiaan, kelancaran layanan publik, dan integritas atau keutuhan data sesuai dengan ketentuan peraturan perundang-undangan.

2. Teori Kewenangan

Telematika bersifat global, sehingga berkenaan dengan upaya kewenangan hukum diperlukan adanya suatu yurisdiksi dalam batasan tertentu suatu negara secara berdaulat. "Yurisdiksi adalah refleksi dari kedaulatan suatu negara, yang dilaksanakan dalam batas-batas wilayahnya". ${ }^{13}$ Pengertian yurisdiksi yang lebih luas dikemukakan oleh B. James George Jr, yang mendefinisikan "Yurisdiksi sebagai kekuasaan negara untuk menetapkan hukum, untuk menerapkan hukum dan untuk menuntut atau mengadili”. ${ }^{14}$

Kewenangan hukum telematika berkaitan dengan unsur-unsur pelanggaran dalam pemberitaan maupun penyiaran yang dapat dilakukan oleh seseorang ataupun kelompok dalam suatu jaringan yang mempergunakan akses internet. Di Indonesia, yurisdiksi telematika yang dipergunakan diatur dalam Undang-Undang Republik Indonesia Nomor 19 Tahun 2016 tentang Perubahan Atas Undang-Undang Nomor 11 Tahun 2008 Tentang Informasi Dan Transaksi Elektronik.

3. Teori Perilaku

Perilaku hukum adalah tentang berlaku atau tidaknya suatu aturan hukum dalam masyarakat, jika berlaku suatu aturan hukum, sejauh mana berlakunya itu dan sejauh mana masyarakat mematuhinya. Teori perilaku hukum merupakan salah satu penganut aliran Positivisme hukum yang lebih melihat hukum sebagai sesuatu yang otonom, atau hukum dalam bentuk peraturan tertulis, artinya karena hukum itu otonom, sehingga tujuan hukum semata-mata untuk kepastian hukum dalam melegalkan kepastian hak dan kewajiban seseorang,

\section{Pembahasan Istilah :}

\section{A. Hoax di Media Sosial}

\section{Pengertian Hoax}

Definisi hoax/hoaks menurut kamus Oxford yaitu: A humorous or malicious deception." Sedangkan hoaks menurut Kamus Besar Bahasa

12 Ibid., Pasal 43 (2).
13 Ibid, hlm: 54.
$14 \quad$ Ibid.


Indonesia berarti "berita bohong". Hoax adalah kabar, informasi, berita palsu atau bohong. 15

Hoax adalah usaha untuk menipu atau mengakali pembaca/pendengarnya untuk mempercayai sesuatu, padahal sang pencipta berita palsu tersebut tahu bahwa berita tersebut adalah palsu. Hoax bertujuan membuat opini publik, menggiring opini, membentuk persepsi, juga untuk bersenang-senang yang menguji kecerdasan dan kecermatan pengguna internet dan media sosial. ${ }^{16}$

\section{Perkembangan Hoax di Indonesia}

Hoax dibuat seseorang atau kelompok dengan beragam tujuan, mulai dari sekedar main-main, hingga tujuan ekonomi (penipuan), dan politik (propaganda/pembentukan opini publik) atau agitasi (hasutan). Hoax biasanya muncul ketika sebuah isu mencuat ke permukaan, namun banyak hal yang belum terungkap atau menjadi tanda tanya.

Di Indonesia, hoax marak sejak pemilihan presiden 2014 sebagai dampak gencarnya kampanye di media sosial. Hoax bermunculan guna menjatuhkan citra lawan politik alias kampanye hitam alias kampanye negatif. Menurut Dewan Pers, di Indonesia maraknya hoax juga karena adanya krisis kepercayaan terhadap media mainstream sehingga publik menjatuhkan ke media abal-abal. Menurut Yosep Adi Prasetyo selaku Ketua Dewan Pers hoax merupakakan dampak berubahnya fungsi media sosial dari media pertemanan dan berbagi sarana menyampaikan pendapat politik dan mengomentari pendirian orang lain ${ }^{17}$

\section{Ciri-Ciri Hoaks}

Ciri-ciri hoaks di media sosial diantaranya $:^{18}$

a. Didistribusikan via email atau media sosial karena efeknya lebih besar

b. Berisi pesan yang membuat cemas, panik para pembacanya

c. Diakhiri dengan himbauan agar si pembaca segera memforwardkan warning tersebut ke forum yang lebih luas. Hoax memanfaatkan iktikad baik si pembaca, sehingga pembaca email ini tanpa meneliti terlebih dahulu kebenaran beritanya, langsung segera

15 Kamus Besar Bahasa Indonesia. Badan Pengembangan dan Pembinaan Bahasa, Kementerian Pendidikan dan Kebudayaan Republik Indonesia http://kbbi.kemdikbud.go.id diakses pada 28 Agustus 2020, pukul 16.00 WIB.

16 Wikipedia. Pemberitaan Palsu. https://id.wikipedia.org/wiki/Pemberitaan_ palsu. Diakses 20 Maret 2020 19.30 WIB.

17 Herlinda. Hoax. http://www.komunikasipraktis.com. Diakses tanggal 20 Februari 2017. 01:55 GMT.

${ }^{18}$ Anto Satriyo Nugroho, Tips Menghadapi Hoax dan Spam. www.ilmukomputer.com. Diakses tanggal 20 Februari 2017, 08:87 GMT. 
menyebarkannya ke forum yang lebih luas. Akibarnya lalu lintas peredaran data di internet makin padat dengan berita yang tidak benar.

d. Biasanya pengirim awal hoax ini tidak diketahui identitasnya.

\section{Faktor-Faktor Penyebab Hoax}

Konten-konten dari Hoaks sendiri sejatinya tidak memiliki batasan, mulai dari agama, politik, kesehatan, bisnis, peristiwa alam yang ajaib dll. Adapun beberapa faktor yang menyebabkan Hoaks dapat tetap bertahan dan eksis pada era kekinian adalah sebagai berikut : ${ }^{19}$
a. Jurnalisme yang lemah
b. Ekonomi
c. Internet
d. Pendidikan
e. Literasi Media yang rendah

\section{Jenis-Jenis Hoax}

Jenis-Jenis hoax misinformasi dan disinformasi, meliputi $:^{20}$

a. Parodi (Satire)

Satire atau parodi, dibuat dengan tidak berniat untuk merugikan, tetapi berpotensi untuk mengelabui..

b. Konten menyesatkan (misleading content)

Konten yang menyesatkan atau misleading content, di dalamnya biasanya ada penggunaan informasi yang sesat untuk membingkai sebuah isu atau individu.

c. Konten tiruan (Imposter content)

Konten tiruan atau Imposter content adalah ketika sebuah sumber asli ditiru atau diubah untuk mengaburkan fakta sebenarnya..

d. Konten Palsu (Fabricated content)

Konten palsu berupa konten baru yang $100 \%$ salah dan secara sengaja dibuat, didesain untuk menipu serta merugikan

e. Keterkaitan yang Salah (False connection)

Keterkaitan yang Salah, atau False connection Ini adalah ketika judul, gambar, atau keterangan tidak mendukung konten atau tidak terikat antara satu dengan yang lainnya.

f. Konten yang Salah (False context)

Konten yang Salah atau False context, ketika konten yang asli dipadankan atau dikait-kaitkan dengan konteks informasi yang salah.

g. Konten yang Dimanipulasi (Manipulated content)

\footnotetext{
${ }^{19}$ Ni Kadek, Loc.Cit.

${ }^{20}$ Wikipedia. Berita Bohong. https://id.wikipedia.org/wiki/Berita_bohong Akses: 28 Juni 2020, pukul 05.08.
} 
Konten yang Dimanipulasi atau Manipulated content ketika informasi atau gambar yang asli sengaja dimanipulasi untuk menipu.

\section{B. Tindak Pidana Hoax Corona di Media Sosial}

1. Peranan Media Sosial terhadap Informasi Corona

Salah satu metode yang digunakan untuk memberikan informasi COVID-19 adalah melalui media sosial, karena penggunaan media sosial merupakan langkah tepat untuk menghindari bertatap muka langsung (kontak langsung), berupa kerumunan di masyarakat. Media Sosial sejatinya merupakan media sosialisasi dan interaksi, yang menarik orang lain untuk melihat dan mengunjungi tautan yang berisi informasi mengenai produk dan lain-lain. ${ }^{21}$

Berdasarkan data Departemen Komunikasi dan Informasi (Depkorninfo) dapat diketahui bahwa di Indonesia saat ini pengguna media sosial mencapai 63 juta orang. Dari angka tersebut menunjukkan 95 persen masyarakat menggunakan internet untuk mengakses jejaring sosial. $^{22}$

Media sosial yang digunakan masyarakat dalam mendapatkan informasi, di antaranya: Instagram, Twitter, Youtube, Facebook, Whatsapp ataupun artikel-artikel pada situs berita online. Beragam informasi dapat diakses oleh masyarakat baik informasi yang diperoleh dari akun resmi maupun yang belum jelas sumbernya dari aplikasi Instagram, Twitter, Youtube dan Facebook. Serta informasi-informasi berupa pesan berantai yang dikirimkan melalui aplikasi Whatsapp, serta artikel-artikel pada situs berita online. ${ }^{23}$

\section{Model Upaya Kepolisian dalam Penanganan Hoax Corona di Media Sosial 1. Jeratan Hukum Hoaks Corona}

Bagi penyebar hoaks, dapat diancam Pasal 28 Ayat 1 UndangUndang Informasi dan Transaksi Elektronik atau Undang-Undang ITE (UU ITE) yang menyatakan "Setiap orang dengan sengaja, dea tanpa hak menyebarkan berita bohong dan menyesatkan yang mengakibatkan kerugian konsumen dalam Transaksi Elektronik", dapat diancam pidana berdasarkan Pasal 45A Ayat (1) UU 19/2016, yaitu dipidana dengan pidana penjara paling lama 6 (met) tahun dan/atau denda paling banyak Rp 1 miliar. Setiap orang yang suka mengirimkan kabar bohong (hoax), atau bahkan cuma sekadar iseng mendistribusikan (forward), harus berhati-hati

21 I Made Adi Widnyana, et al. Covid-19 Perspektif Hukum dan Sosial Kemasyarakatan. Yayasan Kita Menulis. 2020. hlm:54-55. Online: http://google.book.com Akses : 20-06-2020, pukul 02:01 WIB.

${ }_{23}^{22}$ Ibid. hlm:54-55 
PRESUMPTION of LAW

Fakultas Hukum Universitas Majalengka

Volume 3 Nomor 1 April 2021

karena selain denda Rp 1 miliar, pelaku juga akan dikenai hukuman badan, pidana penjara selama enam tahun.

Untuk menekan terjadinya penyebaran hoaks masyarakat perlu literasi untuk meminimalisir penyebaran konten berita bohong. Masyarakat juga dapat melaporkan setiap berita-berita bohong (hoaks) dengan men-screen capture dan disertai url atau dengan dikirimkan ke aduankonten@mail.kominfo.go.id. Kiriman aduan segera diproses setelah melalui verifikasi. Kerahasiaan pelapor dijamin dan aduan konten dapat dilihat di laman web trustpositifkominfo.go.id ${ }^{24}$

\section{Kronologis Awal Munculnya Masalah Penyebar Hoaks Corona}

Pengelola media mainstream seperti media cetak, televisi, radio dan media siber sangat hati-hati mempublikasikan data dan identitas warga yang diduga terpapar virus corona. Diawali dari pengumuman resmi Pemerintah Indonesia melalui Presiders Joko Widodo. Saat itu, presiden menyebut dua warga Depok, Jawa Barat positif terinfeksi Virus Corona awal Maret 2020. Dua warga tersebut pernah kontak dengan warga negara Jepang yang lebih dulu terinfeksi positif corona. Sejumlah media saat itu berhati-hati memberitakan identitas lengkap kedua pasien. Bahkan, warga yang tinggal di perumahan dua pasien tersebut sempat memboikot dan menutup akses bust peliputan media.

Penyebar Identitas PDP Covid-19, diancam Penjara 2 Tahun Polri juga telah memperingatkan masyarakat agar tidak sembarang menyebar identitas pasien Corona di ruang publik. Setiap orang yang melakukan itu bisa diancam hukuman penjara. "Persoalan membuka identitas seseorang pada ruang publik yang tidak berdasarkan izin dari yang bersangkutan, tentunya berpotensi melanggar hukum. Oleh karenanya, perundangundangan sudah mengatur tentang ini semua," kata Kabag Penum Divisi Has Polri, Kombes Asep Adi Saputra di Mabes Polri, Jalan Trunojoyo, Jakarta Selatan, Kamis (5/3/2020) seperti dilansir detik.com. Asep menjelaskan hal itu diatur dalam UU Nomor 44 Tahun 2019 tentang Rumah Sakit dan UU Nomor 12 Tahun 2008 tentang Keterbukaan Informasi Publik. Dalam UU itu, setiap orang yang menyebarkan informasi soal data pasien bisa dipenjara 2 tahun dan denda Rp 10 juta. ${ }^{25}$

\footnotetext{
${ }^{24}$ Masrul, Loc.Cit.

${ }^{25}$ Ibid. hlm: 160.
} 
PRESUMPTION of LAW

Fakultas Hukum Universitas Majalengka

Volume 3 Nomor 1 April 2021

\section{F. Hasil Penelitian dan Pembahasan}

Analisis Terhadap Penanganan Tindak Pidana Hoaks Corona Di Media Sosial Oleh Kepolisian Berdasarkan Undang-Undang Nomor 19 Tahun 2016

\section{A. Tindak Pidana Hoaks Virus Corona Di Media Sosial Yang Ditangani Kepolisian}

\section{Konsepsi Hukum dalam Penanganan Hoax Corona}

Yurisdiksi hukum terhadap kejahatan siber di Indonesia diatur dalam dalam Undang-Undang Nomor 19 tahun 2016 tentang Perubahan Atas Undang-Undang Nomor 11 Tahun 2008 Tentang Informasi Dan Transaksi Elektronik. Proses penegakan hukum yang diterapkan oleh Kepolisian dalam menanganai kejahatn siber hoax coronan adalah hukum positif . Hukum positif yang dimaksud adalah hukum yang berlaku. Hal ini sebagaimana diatur dalam Pasal $28:{ }^{26}$

(1) Setiap Orang dengan sengaja dan tanpa hak menyebarkan berita bohong dan menyesatkan yang mengakibatkan kerugian konsumen dalam Transaksi Elektronik.

(2) Setiap Orang dengan sengaja dan tanpa hak menyebarkan informasi yang ditujukan untuk menimbulkan rasa kebencian atau permusuhan individu dan/atau kelompok masyarakat tertentu berdasarkan atas suku, agama, ras, dan antargolongan (SARA).

Penanganan yang berkekuatan hukum perlu ada obyek dan subyek dari hoax ini. Pertama, berita bohong harus punya nilai subyek obyek yang dirugikan. Kedua, adanya pelanggaran terhadap pasal-pasal yang berkaitan dengan tindakan tersebut. Sedangkan pasal 28 (1) UU ITE terkait berita bohong dengan substansi berdasarkan konten-kontennya masih belum begitu jelas atau kurang spesifik.

Sebagai salah satu upaya maka perlu pengembangan analisis hukum yang lebih jelas secara yuridis, utamanya yang berkaitan dengan substansi berita bohong menyesatkan dalam pasal 28. Hal ini sehubungan secara empiris implementasi dalam kasus penanganan hoax corona yang terjadi di media sosial cenderung memiliki jenis dan tingkat keragaman konten yang berbeda-beda, sebagaimana dilihat pada gambar berikut ini

\footnotetext{
${ }^{26}$ Pasal 28, UU ITE.
} 
PRESUMPTION of LAW

Fakultas Hukum Universitas Majalengka

Volume 3 Nomor 1 April 2021

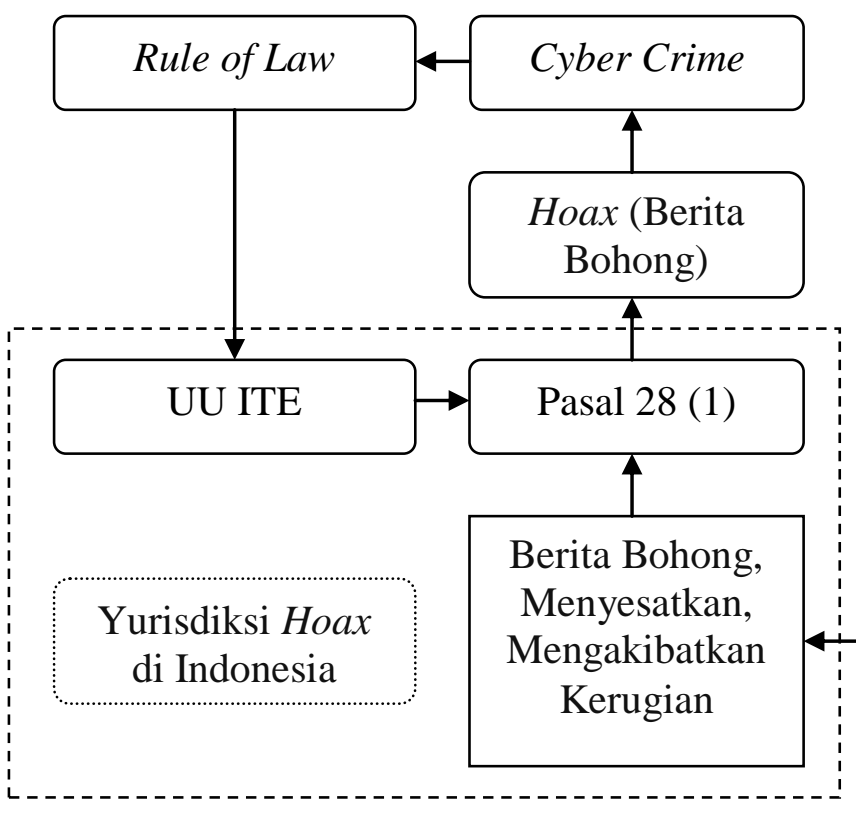

Gambar 4.1

Yurisdiksi Hukum Tindak Pidana Hoax Corona di Indonesia

\section{Analisis Hukum Hoax yang Ditangani Kepolisian}

Tindak pidana hoax di media sosial dalam hal ini bertentangan dengan Undang-Undang Republik Indonesia sebagaimana dalam Pasal 28 (1) UU ITE. Tindakan ini dilakukan memenuhi unsur-unsur kesengajaan dengan adanya modus-modus operandi tertentu dalam membuat, mengunggah, memposting dan menyebarluaskannya di media sosial. Bentuk-bentuk hoax corona dapat berupa ucapan perkataan dalam dengan cara menulis dan memposting dengan perkataan di akun media sosial, melakukan unhggahan, memposting foto-foto ataupun video yang tidak sesuai dengan fakta aslinya bahkan sampai merealisasikannya dalam kehidupan nyata.

Upaya proses hoax secara hukum ditangani dengan melakukan berbagai upaya hukum positif diantaranya melakukan klarifikasi terhadap subjek atau objek yang diberitakan hoax, melakukan screenshoot (tangkapan layar) sebagai alat bukti, melakukan penangkapan, pemeriksaan melalui penydiikan keterangan saksi ahli digital forensik dan petunjuk petunjuk selanjutnya dalam pelaksanaan gelar perkara sampai peradilan. Upaya penegakan hukum yang dilakukan Kepolisian sehubungan penyebar hoax secara yuridis Pasal 28 terdapat dalam Pasal 45A (1) bahwa: ${ }^{27}$

Setiap Orang yang dengan sengaja dan tanpa hak menyebarkan berita bohong dan menyesatkan yang mengakibatkan kerugian

\footnotetext{
${ }^{27}$ Pasal 45A, UU ITE.
} 
PRESUMPTION of LAW

Fakultas Hukum Universitas Majalengka

Volume 3 Nomor 1 April 2021

konsumen dalam Transaksi Elektronik sebagaimana dimaksud dalam Pasal 28 Ayat (1) dipidana dengan pidana penjara paling lama 6 (enam) tahun dan/atau denda paling banyak $\mathrm{Rp}$ 1.000.000.000,00 (satu miliar rupiah).

Dalam hukum pidana di indonesia pelaku menyebar berita Hoax di kenai sanksi dalam pasal 45 A (1) yang memenuhi unsur yuridis:

1. Setiap orang mengandung arti semua orang arti setiap orang disini adalah ditunjukan kepada pelaku.

2. Dengan sengaja dan tanpa hak menyebarkan berita bohong dan menyesatkan Dengan sengaja yang dapat diartikan bentuk kesengajaan dan tanpa hak menyebarkan berita bohong dan menyesatkan,terbukti melakukan dalam hal melaksanakan delik yang diancamkan dalam pasal tersebut.

3. Mengakibatkan kerugian konsumen mengakibatkan kerugian konsumen dalam transaksi elektronik. Yang mengakibatkan kerugian konsumen dalam transaksi elektronik adalah semua bentuk kerugian, tidak saja kerugian yang dapat dinilai uang, tetapi segala bentuk kerugian. Misalnya, timbulnya perasaan cemas, malu, kesusahan, hilangnya harapan mendapatkan kesenangan atau keuntungan sebagianya.Unsur yang terakhir ini mensyaratkan berita bohong dan menyesatkan tersebut harus mengakibatkan suatu kerugian konsumen. Artinya, tidak dapat dilakukan pemidanaan, apabila tidak terjadi kerugian konsumendi dalam transaksi elektronik.

4. Dengan menggunakan media elektronik, orang yang melakukan perbuatan hukum yang dilakukan dengan menggunakan komputer, jaringan komputer, dan atau media elektronik lainnya.

5. Dengan menyalagunakan perbuatan Pasal 28 Ayat (1) dipidana 6 (enam) tahun / dendan Rp.1.000.000.000,00.

Sebenarnya tidak hanya berdasarkan UU ITE tersebut, tetapi lebih mendalam lagi secara pidana dalam Pasal 160: $:^{28}$

Barangsiapa di muka umum dengan lisan atau tulisan menghasut supaya melakukan perbuatan pidana, melakukan kekerasan terhadap penguasa umum atau tidak menuruti baik ketentuan undang-undang maupun perintah jabatan yang diherikan berdasar ketentuan undang-undang, diancam dengan pidana penjara paling lama enam tahun utau pidana denda paling banyak empat ribu lima ratus rupiah.

Demikian halnya dalam Pasal 14 Undang-Undang Nomor 1 Tahun 1946 tentang Peraturan Hukum Pidana yang berbunyi: : ${ }^{29}$

28 Pasal 160, KUHPidana

29 Pasal 14, UURI No 1/1946 
1. Barangsiapa, dengan menyiarkan berita atau pemberitahuan bohong, dengan sengaja menerbitkan keonaran di kalangan rakyat, dihukum dengan hukuman penjara setinggi-tingginya 10 tahun.

2. Barangsiapa menyiarkan suatu berita atau mengeluarkan pemberitahuan yang dapat menerbitkan keonaran di kalangan rakyat, sedangkan ia patut dapat menyangka bahwa berita atau pemberitahuan itu adalah bohong, dihukum dengan penjara setinggi-tingginya 3 tahun.

Pelaku juga berpotensi dikenakan Pasal 15 UU 1/1946, yaitu: ${ }^{30}$

Barangsiapa menyiarkan kabar yang tidak pasti atau kabar yang berkelebihan atau yang tidak lengkap, sedangkan ia mengerti setidak-tidaknya patut dapat menduga bahwa kabar demikian akan atau sudah dapat menerbitkan keonaran di kalangan rakyat, dihukum dengan hukuman penjara setinggi-tingginya 2 tahun.

\section{A. Upaya Penanganan Tindak Pidana Hoaks Virus Corona Di Media Sosial Oleh Kepolisian Secara Yuridis Ditinjau Berdasarkan Pasal 45A}

Terkait dengan pandemic corona dan dalam upaya penanganan hukum yang dilakukan Kepolisian terhadap tindak pidana kejahatan siber yang diantaranya hoax sesuai Pasal 45A, Kepolisian telah melakukan beberapa upaya penanganan diantaranya:

\section{Penerbitan Maklumat Kapolri}

Maklumat Kapolri Nomor Mak/2/III/2020 yang dalam hal ini dikeluarkan setelah adanya penetapan covid-19 sebagai bencana nasional melalui Kepres RI Nomor 12 Tahun 2020. ${ }^{31}$

\section{Layanan Tanggap Covid-19}

Kerjasama dalam penanganan kasus hoax dilakukan Dittipidsiber dalam laporan data dan Humas Polri dalam pemberitaan informasi. Akun resmi Bareskrim Polri melalui media sosial; Dittipidsiber.id, FB: @CCICPolri | IG: @ccicpolri, dan lainnya. Media informasi dilakukan agar masyarakat tidak membuat dan menyebarkan informasi yang menyesatkan.

\section{Patroli Siber}

Kapolri menginstruksikan agar jajarannya melaksanakan patroli siber untuk monitoring situasi berita opini, dengan sasaran hoaks terkait

\footnotetext{
30 Ibid, Pasal 15.

${ }^{31}$ Keputusan Presiden Republik Indonesia Nomor 12 Tahun 2020 tentang Penetapan Bencana Nonalam Penyebaran Corona Virus Disease 2019 (Covid-19) Sebagai Bencana Nasional.
} 
PRESUMPTION of LAW

Fakultas Hukum Universitas Majalengka

Volume 3 Nomor 1 April 2021

covid-19, dan hoaks terkait kebijakan pemerintah dalam menangani wabah virus corona, serta penghinaan terhadap penguasa/presiden dan pejabat pemerintah. Instruksi itu dengan keluarnya Surat Telegram Nomor T/1100/IV/HUK.7.1.2020 per tanggal 4 April 2020

4. Sosialisasi Tentang Hoax di Media Sosial

Kepolisian melakukan upaya sosialisasi informasi pada masyarakat diminta agar tidak ikut menyebarkan informasi-informasi yang tidak jelas sumbernya. Sebab, akan menimbulkan gejolak di tengah masyarakat. Dan masyarakat dapat lebih teliti terhadap segala informasi yang diterima, jangan langsung percaya. Upaya ini dilakukan secara langsung tidak hanya di pusat tetapi juga sampai ke pelososk melalui Humas-humas polsekpolsek terkait.

Secara tidak langsung kepolisan juga bekerja sama dengan kominfo dalam sosialisasi untuk meminimalisir penyebaran konten hoax. Masyarakat juga telah diinformasikan terkait hukuman bagi mereka yang berujar kebencian/SARA melalui UU ITE. Hashtag \#BijakHadapiHoax ramai di Twitter dan pengguna bisa melaporkan apabila menemukan konten di media sosial yang berisi berita bohon atau hoax, ujaran kebencian atau SARA serta radikalisme atau terorisme.

\section{B. Hambatan Penanganan Tindak Pidana Hoaks Virus Corona Di Media Sosial Oleh Kepolisian}

Upaya penanganan tindak pidana hoax corona oleh Kepolisian masih belum maksimal. Hal ini berkenaan dengan masih banyaknya faktor-faktor kendala yang menghambat upaya penanganannya, diantaranya :

1. Lemahnya kebijakan peraturan

Peraturan dalam UU ITE sampai saat ini yang berkenaan dengan hoax hanya terdapat pada pasal 28 yang itupun terbagi dua, pada Ayat pertama tentang hoax (berita bohong) dan Ayat kedua tentang hate speech (ujaran kebecian).

\section{Terbatasnya Aparatur Siber}

Indonesia merupakan salah satu negara dengan masyarakat paling banyak menggunakan media sosial. Sehingga meningkatkan besarnya peluang tingkat kejahatan di dunia maya. Dalam upaya penanganan kejahatan siber sampai saat ini dilakukan Dittipidsiber Bareskrim Polri.

3. Perilaku budaya masyarakat di media sosial

Media sosial berperan penting secara positif dalam menyebarluaskan informasi status secara cepat dan mudah. Termasuk informasi seputar covid-19 dan kebijakan pemerintah yang diterapkan. Namun masyarakat masih awam akibat kekurangtahuan mengenai sumber resmi dalam pemerolehan informasi tersebut, berikut konten-konten hukum

4. Pengaruh hoax-hoax corona dari luar negeri 
Keberadaan hoax yang sumber aslinya dari luar negeri akan menyulitkan dalam proses penegakan hukum, yang mana setiap negara memiliki batas yuridis tertentu. Dalam upaya ini tim siber telah berkerja sama dengan beberapa mitra telekomunikasi penyedia layanan internet positif dengan melakukan pemblokiran. Namun akses langsung secar daring melalui media sosial gadget seperti halnya Whatsapp, tidak sedikit konsumen pengguna media sosial yang terjebak sebagai penyebar dan mereply kembali konten hoax tersebut yang jumlahnya bergitu banyak. 


\section{G. Kesimpulan}

Sebagai kesimpulan akhir dari hasil analisis pembahasan mengenai tinjauan yuridis penanganan tindak pidana hoaks corona di media sosial oleh Kepolisian, disimpulkan sebagai berikut :

1. Tindak pidana hoaks virus corona di media sosial yang ditangani Kepolisian, meliputi konten hoax yang mengelabui/gurauan (Satire), menyesatkan (Misleading), meniru (Imposter), memalsukan (Fabricated), menyalahi (False), manipulasi (Manipulated) dan aksi vandalisme. Penegakan hukum oleh Kepolisian terhadap tindak pidana hoax dalam pasal 28 secara yuridis, dikaitkan dengan Pasal 160 KUHPidana: ancaman 5 tahun penjara, Pasal 14 dan 15 UURI No 1/ 1946: 10 tahun penjara, Pasal 45A UURI No.19/2016: 6 tahun penjara, Pasal 16 UURI No 40/2008: 5 tahun penjara, dan Pasal 14 UURI No. 4/1984: 1 tahun penjara.

2. Penanganan tindak pidana hoaks virus corona di media sosial oleh Kepolisian, meliputi 1) Penerbitan Maklumat Kapolri; 2) Layanan Tanggap Covid-19, 3) Patroli Siber,dan 4) Sosialisasi Tentang Hoax di Media Sosial. Hambatan dalam penanganannya meliputi: masih lemahnya kebijakan UU ITE, terbatasnya aparatur siber yang memenuhi standar di jajaran Polda, perilaku budaya masyarakat yang negatif, dan pengaruh konten hoax dari luar negeri.

\section{H.Saran}

Dari temuan hasil penelitian ini ditemukan beberapa kendala terkait penanganan tindak pidana hoaks corona di media sosial oleh Kepolisian yang diajukan saran sebagai berikut :

a. Pemerintah dapat mengembangkan yurisdiksi perubahan UU ITE lebih relevan, khususnya dalam konten hoax sebagaimana Pasal 28, dengan substansi hukum, jenis, bentuk maupun platformnya dengan pengkondisian Dittipidsiber Kepolisian di berbagai wilayah secara merata dan proporsional, mengingat hampir setiap masyarakat kini merupakan pengguna media sosial.

b. Para pelaku usaha jasa telekomunikasi, media pemberitaan maupun penyiaran dapat lebih meningkatkan peran sertanya secara aktif dalam membatasi konten-konten negatif hoax yang bersumber dari luar negeri melalui upaya internet positif. Sehingga masyarakat pengguna media sosial dapat memanfaatkan akses informasi dan komunkasi lebih bijak lagi dan turut membantu melaporkan status yang terindikasi hoax ke akun resminya, ataupun ke akun aduan kominfo maupun dittipidsiber, untuk menciptakan kondusifitas ketertiban masyarakat secara umum, dan khususnya membantu upaya percepatan penanganan covid-19. 


\section{DAFTAR PUSTAKA}

\section{A. Sumber Buku}

Dikdik Mansur dan Elisatris Gultom. Cyver Law. Aspek Hukum Teknologi Informasi. Jakarta : Refika Adityama, 2009.

Johnny Ibrahim. Teori dan Metodologi Penelitian Hukum Normatif. Malang: Banyumedia. 2013.

Maskun. Kejahatan Siber. Cyber Crime. Suatu Pengantar. Jakarta : Kencana. 2013.

Peter Mahmud Marzuki. Penelitian Hukum Normatif. Jakarta: Kencana. 2005.

\section{B. Undang-Undang dan Peraturan}

Undang-Undang Dasar Republik Indonesia Tahun 1945 dan Pancasila.

Undang-Undang Republik Indonesia Nomor 11 Tahun 2008 Tentang Informasi dan Transaksi Eelektronik

Undang-Undang Republik Indonesia Nomor 19 Tahun 2016 Tentang Perubahan Atas Undang-Undang Nomor 11 Tahun 2008 Tentang Informasi Dan Transaksi Elektronik.

Undang-Undang Republik Indonesia Nomor 2 Tahun 2002 tentang Kepolisian Negara Republik Indonesia.

Undang-Undang Republik Indonesia Nomor 4 Tahun 1984 Tentang Wabah Penyakit Menular.

Undang-Undang Republik Indonesia Nomor 40 Tahun 2008 tentang Penghapusan Diskriminasi Ras dan Etnis.

Ketetapan MPR RI No. VII/MPR/2000 tentang Peran Tentara Nasional Indonesia dan Peran Kepolisian Negara Republik Indonesia.

Keputusan Presiden Republik Indonesia Nomor 12 Tahun 2020 tentang Penetapan Bencana Nonalam Penyebaran Corona Virus Disease 2019 (Covid-19) Sebagai Bencana Nasional. 
Keputusan Presiden Nomor 70 Tahun 2002 tentang Organisasi Tata Kerja Kepolisian Negara Republik Indonesia.

Keputusan Presiden Nomor 89 Tahun 2000 tentang Kedudukan Kepolisian Negara Republik Indonesia.

Maklumat Kapolri Nomor Mak/2/III/2020 tentang Kepatuhan terhadap Kebijakan Pemerintah Dalam Penanganan Penyebaran Virus Corona (Covid-19).

Surat Telegram Nomor T/1100/IV/HUK.7.1.2020 tentang Penanganan Kejahatan Di Ruang Siber.

\section{Sumber Lain}

Alfiansyah Anwar. Polemik Publikasi Identitas Covid-19 dan Sanksi Pidana. Dalam Budiman Et al 19 Covid Pandemi dalam 19 Perspektif. IAIN Pare-Pare Nusantara Press. 2020. hlm: 157. Online: http://google.book.com Akses : 20-06-2020, pukul 01:27 WIB.

Anto Satriyo Nugroho, Tips Menghadapi Hoax dan Spam. www.ilmukomputer.com. Diakses tanggal 20 Februari 2017.

Herlinda. Hoax. http://www.komunikasipraktis.com. Diakses tanggal 20 Februari 2017.

Humas Polri. Update Kasus Hoax Corona 5 Mei : Polri Tangani 101 Kasus https://humas.polri.go.id/2020/05/04/update-kasus-hoax-corona-5mei-polri-tangani-101-kasus.

Humas Polri. Polda Kepri Tangkap Penyebar Hoax Virus Corona. https://humas.polri.go.id/2020/03/17/polda-kepri-tangkap-penyebarhoax-virus-corona.

Humas Polri. Penyebaran Hoax Virus Corona, Polri Amankan 2 Tersangka di Kalimantan Timur. https://humas.polri.go.id/2020/02/04/penyebaran -hoax-virus-corona-polri-amankan-2-tersangka-di-kalimantan-timur.

Ida Bagus Alit Kertawiguna. Paradoks Stockdale sebagai langkah preventif dalam penanganan kepanikan pandemic covid-19 (perpektif bimbingan konseling preventif). Dalam I Ketut Sudarsana, et al. Covid-19 Perpektif Agama dan Kesehatan. Yayasan Kita Menulis. 
PRESUMPTION of LAW

Fakultas Hukum Universitas Majalengka

Volume 3 Nomor 1 April 2021

2020. hlm: 84. Online: http://google.book.com Akses : 20-062020, pukul 02:16 WIB.

I Made Adi Widnyana, et al. Covid-19 Perspektif Hukum dan Sosial Kemasyarakatan. Yayasan Kita Menulis. 2020. hlm:54-55. Online: http://google.book.com Akses : 20-06-2020, pukul 02:01 WIB.

Kamus Besar Bahasa Indonesia. Badan Pengembangan dan Pembinaan Bahasa, Kementerian Pendidikan dan Kebudayaan Republik Indonesia http://kbbi.kemdikbud.go.id diakses pada 28 Agustus 2020, pukul 16.00 WIB.

Kemkominfo. 2020. 177 Jenis Hoaks Virus Corona Beredar di Indonesia. Liputan6.com Update : 09 Mar 2020, 16:19 WIB.

Koronavirus. Wikipedia Bahasa Indonesia Ensiklopedia Bebas. http://wikipedia. or.id. 12 Mei 2020, pukul 11.40.

Masrul, et al. Pandemik Covid-19. Persoalan dan Refleksi di Indonesia. Yayasan Kita Menulis. 2020. hlm:36. Online: http://google.book.com Akses : 20-06-2020, pukul 01:37 WIB.

Ni Kadek Juliantari, et al. Covid-19 Perspektif Susastra Dan Filsafat. Yayasan Kita Menulis. 2020, hlm: 80. Online : http://googlebook.com. Akses: 20-06-2020, 01:48 WIB.

Patroli Siber Akses : https://patrolisiber.id

Polda Maluku. Dua Pelaku Penyebar Hoax Corona Berhasil Di Amankan Pihak Berwajib. https://humas.polri.go.id/2020/03/19/dua-pelakupenyebar-hoax-corona-berhasil-di-amankan-pihak-berwajib.

Polda Metro Jaya. Berencana Lakukan Vandalisme di Tangkot, Komplotan Penyebar Hoax Corona Ini Dibekuk Polisi. https://humas.polri. go.id/2020/04/12/berencana-lakukan-vandalisme-di-tangkotkomplotan-penyebar-hoax-corona-ini-dibekuk-polisi.

Polda Sumsel. Dittipidsiber Ditreskrimsus Polda Sumsel Tangkap Penyebar Hoax Terkait Virus Corona. https://humas.polri.go.id/2020/03/18/ dittipidsiber-ditreskrimsus-polda-sumsel-tangkap-penyebar-hoaxterkait-virus-corona.

Polisi Tangani 101 Kasus Dugaan Hoaks Terkait Corona. Kompas.com 04/05/2020, 19:23 WIB. 
Wikipedia. Pemberitaan Palsu. https://id.wikipedia.org/wiki/Pemberitaan_ palsu. Diakses 20 Maret 2020, pukul 18.30 wib.

Wikipedia. Berita Bohong. https://id.wikipedia.org/wiki/Berita_bohong Akses: 28 Juni 2020, pukul 05.08. 